Check for updates

Division of General Medicine Columbia University Medical Center, New York, USA

2 Red de Salud UC-CHRISTUS, Santiago, Chile

3 Ministry of Health, Jalisco, Mexico

4 William Paterson University, New Jersey, USA

5 Centre for Multidisciplinary Research in Health Science (MACH). University of Milan, Italy

Correspondence to: A PablosMendez:ap39@cumc.columbia.edu Cite this as: BMJ2020;370:m2939 http://dx.doi.org/10.1136/bmj.m2939 Published: 27 July 2020

\title{
Covid-19 in Latin America
}

\section{Responses are complicated by poverty, comorbidity, and political dynamics}

Ariel Pablos-Méndez, ${ }^{1}$ Jeanette Vega, ${ }^{2}$ Fernando Petersen Aranguren, ${ }^{3}$ Hilary Tabish, ${ }^{4}$ Mario C Raviglione ${ }^{5}$

In June, Latin America and the Caribbean became the world's latest covid-19 hotspot with the number of deaths in the region exceeding four million, or over $27 \%$ of the world's covid-19 deaths. ${ }^{12}$ The number of cases in the region is still growing because of resource constrained health systems, a high prevalence of chronic conditions, and delayed responses by some populist governments. Widespread poverty and inequality have fuelled the pandemic and are likely to worsen in its aftermath.

While the world has watched Brazil's predictable disaster, less is being reported about other countries. ${ }^{34}$ Chile has the highest cumulative incidence, yet the lowest case fatality rate. The opposite is seen in Mexico, where reported incidence is lower but the case fatality rate is more than double that of other countries. Although cases are plateauing in the region, 5 the subnational epidemiology of covid-19 is highly variable because of complex internal political dynamics and a mosaic of poverty and inequality.

\section{Chile}

Like much of Latin America, the pandemic reached Chile when the wealthy returned from vacations in the US and Europe. Initially, the government responded with "dynamic quarantines" of the wealthy districts where the first outbreaks occurred. This targeted approach was ineffective because residents quickly infected their domestic employees, who subsequently introduced the virus into their respective communities.

As numbers started to rise, the government increased the availability of intensive care beds and ventilators, but the virus spread aggressively in the absence of widespread community testing and mandatory isolation. By June, Chile had one of the world's highest confirmed infection rates. Although a general lockdown of the economy reduced mortality, it triggered mass unemployment $(11 \%)^{6}$ and a $7 \cdot 5 \%$ decline in gross domestic product (GDP). ${ }^{7}$ The government is providing cash support, food, and low cost credit to small businesses, but these measures are yet to meet the needs of most workers and their families. ${ }^{8}$

\section{Mexico}

When covid-19 arrived in early 2020, ${ }^{9}$ the government declared it an insignificant threat for Mexicans. Some states acted independently and successfully flattened their curve, while others have seen their hospitals overwhelmed. Initial tensions between national and local governments hampered a coordinated response, and the high prevalence of poverty and chronic conditions such as diabetes and obesity meant deaths were not restricted to the high risk elderly population..$^{10}$ Although the government has increased social assistance programmes, they are not sufficient to replace livelihoods for the large number of informal workers. A traffic light colour scheme was developed to indicate infection risk and guide reopening of the economy. Until recently, all states were red.

\section{Central America and the Caribbean}

In Guatemala, the government rapidly locked down the entire country after the first confirmed case in mid-March. However, with $75 \%$ of workers employed informally, many were forced to choose between losing wages and protecting their health, despite some government aid. ${ }^{11}$ The result was over 1000 deaths by mid-July. Cuba also acted swiftly and achieved better control with a community based response and a national emergency plan for border closures, testing, tracing, isolation, and risk communication. ${ }^{12}$ Cuba just celebrated no deaths in the past week ${ }^{3}$ and has begun to reopen tourism. Elsewhere, the Nicaraguan government denied the pandemic threat, and the real burden of infections and deaths remains unknown. ${ }^{13}$

As the pandemic progresses across Latin America three important policy considerations have emerged. Firstly, national leadership and coordination with local governments are paramount, together with clear and trusted communication of risks and measures such as distancing, face coverings, and handwashing. Secondly, countries must deal with asynchronous waves of transmission within their borders by implementing widespread testing, tracing, and isolation of contacts without police repression; isolating sick and elderly people; and ensuring continuity of basic health services, including telemedicine. Thirdly, governments must provide adequate short and medium term financial protection for people in need, with measures such as direct cash transfers to buy food and delaying or waiving payment for essential utilities.

Above all, Latin American governments must act decisively to protect their populations against covid-19 while taking extreme measures to prevent an economic collapse that would exacerbate the region's pre-existing struggle against poverty and inequality.

Competing interests: We have read and understood BMJ policy on declaration of interests and have no interests to declare.

Provenance and peer review: Commissioned; not externally peer reviewed.

Dyer O. Covid-19 hot spots appear across Latin America. BMJ 2020;369:m2182. doi: 10.1136/bmj.m2182 pmid: 32482681

2 Coronavirus HJ. What are the numbers out of Latin America? BBC News 2020 Jul 20. https://www.bbc.co.uk/news/world-latin-america-52711458

3 Johns Hopkins Coronavirus Resource Center. 8 Jul 2020. https://coronavirus.jhu.edu/data/new-cases 
4 Covid-19: the first global pandemic of the information age. 22 Jun 2020. https://storymaps.arcgis.com/stories/a5190c7fd6db422f9a1bab6dac024b99

5 Pan American Health Organization. Covid-19 information system for the region of the Americas. 2020. https://paho-covid19-response-who.hub.arcgis.com

6 Chilean National Institute of Statistics. https://ine.c//inicio

7 Banco Central de Chile. https://www.bcentral.cl/contenido/-/detalle/banco-central-publico-informede-politica-monetaria-ipom-de-junio-de-2020

8 Atria J, Grau N, Sanchez V, et al. La política económica frente al COVID-19 en Chile y el mundo: una invitación a ampliar las fronteras de lo possible. 5 May 2020 https://ciper-

chile.cl/2020/05/24/la-politica-economica-frente-al-covid-19-en-chile-y-el-mundo-una-invitaciona-ampliar-las-fronteras-de-lo-posible/

9 Suárez V, Suarez Quezada M, Oros Ruiz S, Ronquillo De Jesús E. Epidemiología de COVID-19 en México: del 27 de febrero al 30 de abril de 2020. Rev Clin Esp (Barc) 2020. doi: 10.1016/j.rceng.2020.05.008

10 Bello-Chavolla OY, González-Díaz A, Antonio-Villa NE, etal. Unequal impact of structural health determinants and comorbidity on COVID-19 severity and lethality in older Mexican adults: Considerations beyond chronological aging. J Gerontol A Biol Sci Med Sci2020; doi: 10.1093/gerona/glaa163. pmid: 32598450

11 Cahier L. La pandémie de Covid-19 au Guatemala: la perspective des femmes autochtones. 21 May 2020. https://covidam.institutdesameriques.fr/la-pandemie-de-covid-19-au-guatemala-laperspective-des-femmes-autochtones/

12 Gorry C. Covid-19 case detection: Cuba's active screening approach. MEDICC Rev2020;22:58-63. doi: 10.37757/MR2020.V22.N2.16 pmid: 32478711

13 Pearson AA, Prado AM, Colburn FD. Nicaragua's surprising response to COVID-19. J Glob Health 2020;10:. doi: 10.7189/jogh.10.010371. pmid: 32612814

This article is made freely available for use in accordance with BMJ's website terms and conditions for the duration of the covid-19 pandemic or until otherwise determined by BMJ. You may use, download and print the article for any lawful, non-commercial purpose (including text and data mining) provided that all copyright notices and trade marks are retained. 